DOI: 10.1515/ausfm-2015-0029

\title{
How Long and When: \\ Open Time Interval and Dignified Living Creatures in The Turin Horse
}

\author{
Zsuzsa Selyem \\ Babeş-Bolyai University (Romania) \\ E-mail: selyemzsuzsa@lett.ubbcluj.ro
}

\begin{abstract}
László Krasznahorkai wrote two different texts (the second being the script of Béla Tarr's film) from two different perspectives starting from the well-known scene in Turin, Italy, where Friedrich Nietzsche embraced a horse beaten severely by the carter. Why does the interpretation of the Nietzsche-scene change? What kind of temporal, historical or ethical relationship does the differentiation between the two texts depend on? How can the beauty of the crumbs of life be perceivable? This article argues that in these works - in contrast with the commonly assumed precognitions about apocalyptic art - life and humble living creatures are celebrated.
\end{abstract}

Keywords: compassion, László Krasznahorkai, Friedrich Nietzsche, open circle, Béla Tarr.

\section{Why Embracing the Beaten Horse?}

László Krasznahorkai’s essay, At the Latest in Turin (2013), was written in 1979, but firstly appeared only right after the regime change in Hungary, in the January 1990 issue of the Alföld journal. There he muses on the inherent contradiction of the well-known Nietzsche-scene in Turin: why did the philosopher, who considered all human compassion a weakness, embrace the horse and not the carter flogging it? Then Krasznahorkai concludes that compassion is what expresses our craving for existence, connects us with some kind of a (very cautiously said) "larger whole" and that this compassion, sometime, "tomorrow... or in ten... or thirty years" has to come into being, "at the latest in Turin," he adds (Krasznahorkai 2013, 26).

Some thirty years later, Béla Tarr made the film The Turin Horse (A torinói ló, 2011), having its script co-written with the novelist László Krasznahorkai. (They 
had been working together for a long time; Krasznahorkai's novels constituted the sources of such films as Satantango [Sátántangó, 1994] and Werckmeister Harmonies [Werckmeister harmóniák, 2001].) Krasznahorkai published the script of The Turin Horse on his personal website, and added the following remark to the list of his works he used for the script: "created with Béla Tarr's thoughts and ideas, for his spiritual recovery" (Krasznahorkai 2004).

The script starts with the text published in 1990 (but written about thirty years earlier), yet continues elsewhere. "What happened to the horse, we don't know"the script, marking the year 2004 as the date of its creation, leaves the former prose behind with this sentence.

Why does the interpretation of the Nietzsche-scene change? What kind of temporal, historical or conceptual relationship does the differentiation between the two texts depend on? How does Krasznahorkai make time perceivable in his two works? And how does Béla Tarr make time perceivable in The Turin Horse?

The difference that strikes at first glance: while the merely three pages long prose of the At the Latest in Turin talks about the endgame of our spirit - with some allusions to great European thinkers, the script, besides the prologue about the collapse of Nietzsche's mind, does not mention anything related to spirit, reason, rationality or even irrationality. More specifically, the essay - besides speaking about Friedrich Nietzsche, who reactualized the ancient Greek world in the $19^{\text {th }}$ century, who considered Christianity the manifestation of envious resentment (ressentiment), who sketched the myth of the eternal recurrence, who represented truth as an unattainable woman, who announced the death of God - mentions three further personalities. There is doctor Paul Julius Möbius, one of Nietzsche's doctors (in whom, by the way, we can honor the author of the tractate Über den physiologischen Schwachsinn des Weibes [1977], printed in nine editions during his lifetime), then there is Thomas Mann, whose attitude towards Nietzsche's mistake is being recalled in this work, and Immanuel Kant appears as well, whose work secured the coming of age of human mind. On the contrary, the script presents day-to-day living as concretely as possible: getting dressed, eating potato, sitting in front of the window, housework, tending animals. Krasznahorkai's famous long sentences, with their specific rhythm and repetitions, here, deprived of all poetry, give us only the mere rhythm and repetition itself. If they are still beautiful, it is not because of the composition but because of the feeling that the repetitiveness of bare material existence is still beautiful.

It is beautiful compared to the pervasive darkness. 
Secondly, in his prose Krasznahorkai calls Nietzsche's sobbing while embracing the beaten horse "the dramatic model of the intellect" (Krasznahorkai 2013, 24). He revealed that in less than thirty years people would relate to each other with compassion. These thirty years have long expired since 1979. If that was the prophecy (and if it was a prophecy at all), it turned out to be more than false. If it was not a prophecy but an apocalyptic vision in the original sense of the

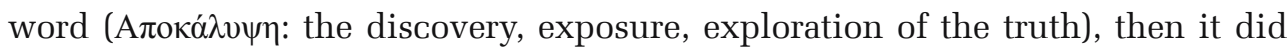
not concern the future at all, but rather all times (каıро́), and can be false or true from moment to moment. Krasznahorkai, then, expressed a vision about words or questions concerning some kind of a "larger whole," a "higher law," moreover "the meaning of a higher law," even if gloom, as he wrote, absorbs them. In an interview made between the August and October of 1989, Krasznahorkai spoke ironically about these candid wishes: "I wrote a short reflection a few years ago related to Friedrich Nietzsche, approximately with the gentle call 'be good, otherwise you will regret it.' Of course, we could talk about the other side of the issue as well, namely that 'you will regret it even if you are good;' yet approaching now the question from the other direction, I am the follower of that undeniably aristocratic spirited agreement under which we wouldn't really insist - at least here in Hungary, for a while - on the question of how big the distance between Kant's moral law and this law's mandatory constraint actually is" (Keresztury, 124-125).

The so to speak bright, optimistic, meaning- and value-searching presentation of the Nietzsche-scene is given from a larger, post-Kantian perspective, from which goodness or honesty is not necessarily the human subject's inner reality. However, At the Latest in Turin talks only about the exceptional, in the illustrious company of Thomas Mann and Immanuel Kant. The interview makes it clear that the author gave a privileged direction to his text because he took into account a narrower space-and-time system, the soft-dictatorial Hungary before the 1989 turn. Those times were characterized by scams and sacks, people sank from poverty to deeper poverty, the Irimiás of the Satantango, the Prince of The Melancholy of Resistance were tiny but dangerous figures with their apparatuses built around them. Somehow these figures always manage to have enough power to persuade the poor, hopeless and silly people to contribute to their own and everything else's devastation.

After the 1989 turn, when Eastern Europeans could not anymore hide from themselves that poverty was a global characteristic of a great part of human beings, László Krasznahorkai, in a fictitious lecture, evoked a scene from Berlin: in August 1992, at the Zoologischer Garten metro station an old, shaky homeless 
man was urinating on the forbidden stretch separated from the rails with a cordon (Krasznahorkai 1993, 34-51). He was observed by two policemen standing on the other side, and even though they were separated only by ten metres, those had to climb the stairs to catch him as the ten metres were impossible to be crossed directly because of the rails. Krasznahorkai interpreted those ten metres as the presence of evil and good, stating that unfortunately, there is no traffic between the two, and that similarly unfortunately, one decisive detail of the world is enough to make the whole world unbearable.

The text written in 1979, naming the scene of Nietzsche and the horse the tragedy of the intellect, does not make perceptible this idea concerning "the whole world," yet the ten metres distance between everything and everything cannot be felt, and the twenty-three-year-old Krasznahorkai talks only about the sad freedom of the violation of the Kantian moral law (and not about the uncanny lack of it).

"Nothing terrifies me more than this starred nothing above us and this hungry stomach inside us" (Krasznahorkai 1992, 47). Krasznahorkai’s later crystallized version on Immanuel Kant's captivating sentence from the Critique of Practical Reason accurately indicates the direction in which the scene with Nietzsche and the horse from the script will be elaborated. Nietzsche becomes a quotation deriving from the former text, and all the sentences begin to refer to the strict necessities of material existence during the six days through which the essential condition of life is gradually disappearing.

"The first pieces are very hot, Ohlsdorfer throws them in the air with his left hand to cool them, and the girl throws them from one hand to the other, and they both blow them until they manage to peel them. They chew munching, puffing, breathing; they swallow the potatoes, one after the other. They chew, swallow, peel and salt until the last piece is stuffed down their throats. Then the girl stands up from the table, and she throws the collected potato peels in the corner near the stove" (Krasznahorkai 2004). The text is identically repeated four times: on each day of the six, except the third, when the gypsies arrive, and the sixth day, when they eat bread and bacon (raw potatoes in the film) because even the fire has gone out.

It is not only the identical repetition, the daily routine that makes the situation perfectly pointless, utterly desolate, but the barrenness of eating, too. Potato and salt, chewing and swallowing: the great temptation of material existence, the sensuousness, the pleasure of the flavours are nowhere, father and daughter eat as executing a duty. In the film, this is pronounced drily, banally, heard a thousand times: on the sixth day, when the girl does not touch her potato anymore, the father roughly says to her: "Eat. One has to eat." 
In the context of art history, this dreary eating recalls a turning point in visual arts from the $19^{\text {th }}$ century, Van Gogh's The Potato Eaters (1885). The painting scandalized people in its time as it did not fit the pathos-convention required in the portrayal of peasants. In Béla Tarr's approach, the images of potato-eating move on from Van Gogh's realism towards simple, geometric forms. Tarr's images do not target the new, they target the eternally comfortless.

Let us consider, for example, the barely levelled table without a cloth on it and with a platter in its center shown in the film for seconds. Or let us try to interpret the complicated, detailed poverty of the art of cinema discovered by Béla Tarr watching the repetitive potato-eating over the four days, shown each day from a different angle. We will discover new features, different lines and gestures, various forms of greed and satisfaction, of vulnerability and routine. We can see the infinity, not some definitive closure; as Jacques Rancière put it, the closed circle is always open in Béla Tarr's films (Rancière 2011).

Thirdly, the fact that the film relates itself to a Van Gogh painting opens to us another connection to the early Krasznahorkai-text, the At the Latest in Turin: Kant's beautiful sentence about starry heaven and moral law engraved on the philosopher's gravestone ("Two things fill the mind with ever-increasing wonder and awe, the more often and the more intensely the mind of thought is drawn to them: the starry heavens above me and the moral law within me") can be interpreted in the context of Van Gogh's last - and also infinity-related - sentence uttered on his death-bed: "The sadness will last forever."

The time when the painting was created, 1885, is close to the day when Nietzsche met the horse, cried, and spent his remaining time in silent mental illness. Mental breakdown connects Nietzsche and Van Gogh (especially if we take into account one of its possible reasons, the syphilis infection discovered in both cases), and separates them at the same time: Van Gogh painted until the end of his life, anywhere, in any mental condition, while Nietzsche spent his days in his parents' house, sitting in front of the window all day long, for the rest of his life.

In The Turin Horse, the sitting-in-front-of-the-window is a day-by-day performed situation taken in turn by the father and the girl. Gaze and image, philosophy and art go through the most basic democratization in Béla Tarr's works: he entrusts fallen, struggling, trembling-voiced people with both processes.

What is not visible in the film but is clear in the script and the cast: two writers, Thomas Bernhard and Heinrich von Kleist are also invoked in The Turin Horse in a similarly democratizing way, making the exceptional approachable and common. The name of the father is Ohlsodorfer, and Ohlsdorf is the name of the 
Austrian village where Thomas Bernhard lived for years, where nowadays the Bernhard memorial museum can be found and visited.

The script and the cast contain only two proper names, one is the mentioned Ohlsdorfer and the other one is Bernhard. The latter is the name of the man who visits the Ohlsdorfers to purchase brandy from them. (His profession will send us to Heinrich von Kleist, but let us stick to Thomas Bernhard for now.)

The Bernhardian rhythm of the sentences, the musicality created by repetitions, interpositions, escalations and accumulations can be perceived in Krasznahorkai's script (actually in all of his scripts). Think of the potato-eating described four times, the enumeration of verbs, the details and the interpolation. The never-ending tirade about the end of times pronounced by the neighbour called Bernhard is even more Bernhardian. We can see here another process of democratization: Thomas Bernhard's musicality - traversing through the short story Isaiah has come by Krasznahorkai (1998), where the drunken local historian, György Korim declaims the general ruination of the world in a non-stop snack bar of a bus station - becomes the neighbour's words.

The logic of resentment would indicate that Krasznahorkai, in an infinite selfcenteredness, quotes only himself, but from the perspective of the ability to feel the joy of life, this is the process of democratization of the text: if the drunken local historian or the neighbour is capable of this musicality of the words, then everybody is. And the fact that the name of this orator neighbour endowed with Bernhardian musicality is, after all, Bernhard, is a hidden reference that might not have been known even to the Mann- and Kant-quoting early Krasznahorkai back in 1979. (Namely, a reference to the fact that respect has nothing to do with cult.)

Now let us pass to the second hidden tribute to another literary predecessor. The neighbour, by profession, is a horse dealer, according to the script.

\section{Kant, Kleist, Nietzsche and the End of the $19^{\text {th }}$ Century}

Horse dealer as the neighbour's occupation in itself cannot be taken as a strong argument for Michael Kohlhaas's being in our playground, but there is more: the writer of the story, Heinrich von Kleist went through a cognitive-psychic period, which he named "Kant-crisis," and after which he decided to drop scientific research. So, the naïve Kant-reference from the early prose of the At the Latest in Turin turned into a preachy horse dealer neighbour in The Turin Horse.

László F. Földényi's insight helps avoiding this Kant-absence to be turned into a disappointed withdrawal (Földényi 1999). Földényi demythicizes the Kant- 
crisis itself, which in his opinion is nothing else than the monotone illusion of Kleist-interpreters by which they seek a rational explanation for his unutterable gift, reducing the source of Kleist's creative power, the art of expressing the sudden revelation of irreconcilability to a feeling of despair. Földényi argues that the term "Kant-crisis" appearing in Kleist's letter is a post-formulation for Kleist's personal experiences, namely that virtue "cannot be objectivized," and if the one I loved more than anything leaves me, I will become empty again.

"And in that moment, outside the lights suddenly go out" (Krasznahorkai 2004). Krasznahorkai informs us in this sentence that permanent darkness has come. In the SUDDENLY entry of his Kleist-dictionary, Földényi connects this concept to an absolute present tense, which breaks away from the past but does not connect with the future either.

According to the script, this final darkening occurs on the fifth day.

The fifth day of what?

The prologue indicates the time of the scene with perfect precision: 3 January 1889. But henceforward, in the film itself, besides the horse, $a$ horse, there is no other connection to the Nietzsche-scene. The film is precise in expressing how long it lasts, but it does not say exactly when it happens. Through six days, things disappear one by one from life: on the first day the scratchy sound of the woodbeetles dies away, on the second day the horse will not get going, on the third day the horse does not eat anymore, on the fourth day the well runs dry, on the fifth day the fire goes out, the wind stops blowing, the light disappears, on the sixth day the girl does not eat anymore.

The five-day-windstorm is a natural phenomenon, it has nothing to do with the time structured by human beings. The way of life of the characters is not culturally organized either, it adjusts only to nature: to the sunrise, to hunger, to pain, to darkening.

Beyond a certain level of poverty, people are excluded from the culturally organized time. Exclusion can reach a scale where social relations are replaced by cosmic relations. This is why Krasznahorkai's and Béla Tarr's characters, no matter how humiliated and distressed, do not appear as claiming our compassion. The environment researcher Angela Last writes on her blog that The Turin Horse could be described as "Melancholy for the 99\%" (cf. Last 2012).

The characters of Krasznahorkai and Tarr, except for the neighbour Bernhard, barely speak more than the horse. Talking does not lack from these scenes. Even more, there is something violent, not fitting in every word they use, and not only because most of their words are obscenities, but rather because there 
is nothing to talk about here. One of the strongest symptoms of this absence is the addressing form without names, the "Hey, you!" characterizing the fatherdaughter relationship. At some point, before the script and the six days of the film, the girl's name disappeared, and what is left is mutual exposedness to each other, coordinated, pragmatic movements deprived of any tenderness, automatic consideration for each other's territory.

These characters do not demand our compassion or envy, Krasznahorkai and Béla Tarr do not fulfill the actual expectations of pity or desire fulfillment. They talk about people as respectful beings, regardless of the circumstances they find themselves in. They do not offer to their public the self-sufficient pleasure of the exoticism of depravity and of being privileged. They have no wish to feed such low and illusory desires. Or as Béla Tarr says in an interview: they consider the audience their partner (Valuska 2008).

In political culture, this is called participatory democracy. It is not accidental that one of the contemporary philosophers of emancipatory politics and aesthetics, Jacques Rancière wrote a book about Béla Tarr's films (Rancière 2011). These films visualize everything he writes on the extension of the sensible, give voice to the "silent witnesses." Here we have everyday items considered insignificant before, but in fact symptoms of social issues, which can be perceived sooner in literature (and arts) than in history.

The suddenness of darkening, the horse dealer and the turn called Kant-crisis make the hidden reference to Kleist's world perceptible in The Turin Horse. According to Földényi's SUDDENLY entry in his Kleist-dictionary (Földényi 1999), the accentuation of the moment, of the "sudden" in Kleist's works gives the impression that the author emancipates the "nothing" itself. Not only time has cracked, conversation is pointless too.

The six-day-long gradual darkening with a sudden end could happen almost anytime, even now. The only concrete indication of the era is the telegraph in the script and a photograph of the mother in the film.

According to the script, the horse dealer neighbour, postmaster for a while, when coming for brandy for the second time on the fifth day, eulogizes the news that darkness has fallen on every continent, and darkness has fallen forever, and he knows this because as a former postmaster he owns a telegraph, by which he can learn anything that happens in the world, even in a remote place as theirs.

The telegraph was invented in 1837 by Samuel Finley Breese Morse, and it quickly spread worldwide. We would suppose, the long-distance information exchange made possible by internet connection and mobile phones displaced it 
long before our days. It is not quite so: the last telegraph business in India closed down on 14 July 2013, actually a few years after The Turin Horse appeared.

The invention of photography was declared on 7 January 1839, in front of the French Academy, by the astronomer François Arago, protector of the inventor Louis Daguerre, and from the August of the same year it spread unbelievably quickly. It seems that also photograph is disappearing in the era of computers, smart phones, projectors and tablets. Both technical devices indicate the $19^{\text {th }}$ century as the time of The Turin Horse. Presently, they are being replaced by other platforms using up energy even when not working. It is not so hard to imagine a situation when the dependence of energy of these means would result in a return to those old things from the $19^{\text {th }}$ century. Then the time structure of The Turin Horse would open from the right, but for now, the possible time of the events is an interval closed from the left, while the happening itself, the process of darkening is closed from the end, from the right. If we homogenize the two types of time, the historical and the artistic, we obtain a closed time interval. In other words, for the time frame to be limited, closed (necessarily at a good distance from us), we have to commit an unforgivable logical fault: we have to project the time parameters of the two different systems on one, arbitrarily selected line.

Friedrich Nietzsche wrote in his Use and Abuse of History for Life: "For art runs away, when you instantly throw over your actions the roof of the historical marquee. The person who wants to understand, calculate and grasp in an instant, where he should in an enduring shock hang onto the unknowable as something sublime, may be called intelligent, but only in the sense in which Schiller speaks of the understanding of the intelligent person: he does not see some things which even the child sees; he does not hear some things which even the child hears; these 'things' are precisely the most important thing. Because he does not understand this, his understanding is more childish than the child's and more simplistic than simple mindedness, in spite of the many shrewd wrinkles on his parchment-like features and the virtuoso practice of his fingers unraveling complexities." (Nietzsche 2013.)

If we do not choose the arbitrary, calculated simplicity, we can conclude that the darkening process beginning in the $19^{\text {th }}$ century ended only according to the script and the film but in reality, where telegraph, photography, Nietzsche and perhaps the horse originate from, in reality it has not ended.

Let us return again to the collapse of Nietzsche's mind as it was written by Krasznahorkai in 1979: the diabolical star of the philosophy of life, the dazzling opponent of the so called "universal human truths," the inimitable champion 
saying no almost until out of breath to compassion, forgiveness and goodness admits his tragic mistake. "Nietzsche's personality said no to Nietzsche's thoughts so hellish in their consequences" (Krasznahorkai 2013, 24). Does the reality, the unattainable, the Kantian Ding an Sich, gathering its last strength, in the guise of a beaten horse break the beautiful, courageous fiction?

But let us consider it longer: could Nietzsche have been indeed shaken by the exotic, distant, self-existent, not-concerning reality? Or, from another point of view, is it beneficial to reduce a doubtful episode to a conflict between reality and art, intellect and subject, from which then we can beautifully deduce the madness of the artist? I cannot stave off the idea that the philosopher, who vehemently rejects compassion as a coward form of self-defence, has caught a glimpse of himself in the trapped horse, hasn't he? (At least, this would be a chance to avoid interpreting the anecdote in a pathetic way, to avoid feeling pity for our fellowbeing, Nietzsche, in the false sense of our primacy.)

In a well-known studio photograph made in 1882, obviously destined to be funny, Nietzsche and Paul Rée pose as they were horses fixed to a sort of carriage, and their mutual love, Lou Andreas-Salomé is looking at the camera with a whip held up in her hand. In conformity with the habits of those times, the background of the photograph made with innocent falsity is a painting of an Alpine landscape, while the persons appearing in the image pose in light, elegant, heavily buttoned urban clothes. It is a perfect copy of artificiality, scandalous and sublimating at the same time: the woman with a whip in her hand takes on the gesture of audacity, but her moves, her posture, the Brechtian Haltung cannot yet follow this audacity with the corporal articulation of the feelings. And the men stand rigidly in their formal attire in front of the camera as they were standing in the world's most natural posture, say in a café's billiard room reserved for men. Rée is posing elegantly, barely touching the carriage rod with two fingers, Nietzsche is looking somewhere (surely, in the nothing emancipated by Kleist), while behind their back there lie the picturesque Alps. However, there is still some inexpressible reality lurking in the picture, the Turin reality.

Since then, people have experimented with lots of authentic situations corresponding to their feelings. The solution to the Nietzsche-scene in Krasznahorkai's script and Béla Tarr's film depends on the simultaneous cooperation between two, respectively three things. The first one could be called "the representation of the woman."

On the wall, near the girl's bed, there is a photograph of the missing mother, which we could not see from close until the girl started to pack up. As I have 
indicated before, the photograph of the mother in the movie does not appear in the script. Moreover, there is nothing in the script that hints at the mother or her absence. The mother's image appears in a close-up only during the break out attempt in Béla Tarr's film (and it is time to write down the name of his codirector, Ágnes Hraniczky), which timing makes the missing woman perceptible as an absent, dignified human being. The accurate circumscription of the missing mother's place is the portrayal of a woman without any simplification, the portrayal of the woman in her hidden but possible complexity. Additionally, it reveals a $19^{\text {th }}$-century convention which saw either a saint or a prostitute in a woman (rather the latter in the prologue and background of our story).

The second feature contributing to authenticity is the slow-motion, six-daylong process of the termination of life conditions. The third one is the manner of the useless break-out attempt after the well has dried up; the only explanation added to it being: "we can't stay here any longer, pack up" - so when they do not have water either, and the father feels that they have to go away somewhere, they put all their things on a cart and while the father leads the horse unable to move from its bridle, the girl's job is to pull the terribly heavy cart.

She is moving slowly with the cart, we have time to observe the struggling body under the weights not designed for it to bear. Speaking would only cover what this scene can show. In accordance with Bertolt Brecht's usage of the notion of posture or gesture, here as well, the body can reveal the interpersonal and social relationships so that the viewer (because in Brecht's approach the viewer is in the centre) recognizes the conventions which motivate the actions of individuals (cf. Brecht 1964).

Béla Tarr does not sublimate: in his Nietzsche-scene, humans, existing together with animals, $99 \%$ of the population of the Earth can share the recognition that it is him- or herself pulling - totally unnecessarily - the overloaded cart.

\section{"You Are Nowhere. The World Is but Thin Air." (János Pilinszky: Apokripha, 1954)}

Three horses appear in Béla Tarr's film, the horse of the Ohlsdorfers and the two horses of the gypsies. The three horses have no special meaning, four would have, for sure. But the horse of the Ohlsdorfers pulls a carriage built for two horses, it is hooked in on the left side while its partner on the right side is absent, which makes the first seven minutes of the film even more difficult with the seemingly endless journey of the horse and its carter in the wind attacking them from every side. 
The girl pulls the cart from the left side as well when they are trying to escape, so the two situations are not transposable, not even if we remove the temporal discrepancy in the hope of some sort of an eternal simultaneity, some kairos; not even if we could imagine that they can help each other in the name of equality between living beings. They cannot help each other because that is not how they are positioned. They are both hooked up in such a way that their partner would be absent from their side.

The gypsies and the two horses appear with a Kleistian suddenness on the third day; Krasznahorkai actually uses this expression in the script: "Then suddenly a wagon appears from the left in a mad gallop, with lots of gypsies in it" (Krasznahorkai 2004). They leave just as suddenly to the right, towards west, after giving a book to the girl. The appearance of the gypsies, after the visit of the horse dealer Bernhard, is the second event that occurs in the everyday life of the Ohlsdorfers. (In the script, Krasznahorkai creates two visits of Bernhard, the second happening after dark, but in the film Bernhard comes only once.)

These two events breaking into the world of the Ohlsdorfers could be considered as the two focal points of an ellipse, just as in the case of Kleist's short story, Michael Kohlhaas, where the episode about the horse dealer's efforts to recuperate his horses is followed by the enigmatic story of a gypsy woman. The film searched for a stronger link with the Kleistian short story about the horse dealer. In this, besides the political level, an incomprehensible, otherworldly tale starts about a gypsy woman having a birthmark in the same place as Lisbeth, Kohlhaas's wife, who died during her search for political fairness. Looking at the two visits in the film from this point of view, the neighbour Bernhard offers the political interpretation of the events while the gypsies are the mediators of a different, incomprehensible knowledge. They, similarly to the dual being of Kleist's gypsy woman/Lisbeth, know something unreachable for the others: they move freely in the wind-storm, they give away a book which evokes and withdraws holiness in a state of swoon, ignorance and audacity. (In Kleist's story, the gypsy woman gives Kohlhaas a leaden case containing a prophecy, and the corrupt prince, who the prophecy refers to, faints when he sees the case hanging in Kohlhaas's neck.)

The girl reads the book falteringly, and opposed to the similar scene in Andrei Tarkovsky's Stalker (1979), reading is not glorified here, the book and the reading girl are not angelic mediators at all. The girl, although a grown up (drinks her glass of brandy every morning with her father), reads poorly and there is no sign of understanding on her face. The stumbling, stuttering reading leaves her and the spectator in the most complete intellectual darkness. Moreover, if we look up 
the script, we learn that the book itself is preaching about the incapability of both humans and God. The prayers in this book are reversed prayers: "Do not pray! For our minds are not filled with truth, and we are not glorified before the Lord. And do not accept, Lord, the gifts of your bitter congregation because in this sanctified house your people did not achieve eternal salvation through the holy secrets." It uses Christian language but only to annihilate it. It negates the addressed God's power to save the person turning away from Him, which, according to the Christian teachings, is equal to denying Grace. There is nothing in this book but man's sinfulness and confusion; and what the so-called Ordinary preaches to the congregation is the greatest sacrilege: "The Lord was with you!" - by which, after depriving God of His omnipotence, deprives Him of His eternity as well.

In the film, the meaninglessness of the sacrilegious holy text is expressed by the syllabic, dull, monotonous reading process that lacks any meaning and interpretation. In the only medium available for the script, this senselessness, this loss of meaning is made doubtless by making the text chaotic: the girl reads twenty-six paragraphs, but the twenty-third appears twice and the twentyfifth is missing; it is also chaotic that the articles randomly include laws, mere invocations, descriptions, or some out-of-context formulas. The seventh paragraph is especially ridiculous regardless if we try to read it as a holy teaching or as part of a ritual: "The congregation remain silent."

According to this ceremonial book detailing the liquidation of the church, there is neither God, nor congregation anymore. There is no one left to swindle people, as Irimiás did in Satantango, and there are no swindled, deluded people anymore. There is only a girl articulating the words with difficulty, without understanding them, in a house where nothing suggests (except for the photograph of the missing mother in the film) that it has ever been somebody's home. And outside, the storm rages on.

Béla Tarr creates the negation of continuous eternity with two allusions to paintings: firstly he films the father lying on the bed in order to hint at Hans Holbein's The Body of the Dead Christ in the Tomb (1520-1522), secondly he shows him in a way that reminds of Andrea Mantegna's Lamentation over the Dead Christ (1480). Hinting at Holbein's painting, the film not only creates an analogy between Ohlsdorfer and the dead Christ, but it also includes in the context the loss of the relationship between belief, congregation and God. One of the strongest interpretations of Holbein's painting can be found in Dostoyevsky's novel, The Idiot, in the famous scene where Prince Mishkin, seeing this painting on Rogozhin's wall, says that this painting can make a person lose their belief. The 
title of the novel and its main character can reveal further connections: Mishkin's figure, the idiot, according to the writer's intention, is meant to embody the figure of Jesus; his age (twenty-six) corresponds with the number of the commandments - or whatever they might be - of the chaotic holy book in the script; and the candid soul claims that beauty will save the world.

If anything, then yes, beauty. Julia Kristeva says something similar in her essay, Holbein's Dead Christ: "the form (of art) alone gives back serenity to the waning of forgiveness, while love and salvation take refuge in the execution of the work. Redemption would simply be the discipline of a rigorous technique." (Kristeva 1989, 135.)

The Turin Horse is even more rigorous in its technique than the earlier works of Tarr. This film contains the longest cuts, only thirty in the 147-minute-long film. The number thirty can be familiar from Krasznahorkai's prose, remember: even if there is no compassion in us yet, tomorrow, or in ten or thirty years there will be. This human disposition was problematic not only in connection with the Nietzsche-scene, as I argued above, but also Krasznahorkai abandoned any further proceeding in this direction. He chose to describe the struggles of the elementary material existence, to create forms for representing wretchedness where no apparatus of power can be considered responsible for the condition of the abject. The beauty of the repetitions surrounding the hidden focus points of the mere material existence is what is able to create an open structure. The openness of this structure can be sensed strongly due to a pair of opposite and very slow images: the vertigo of the dried up well that seems to drag one into itself set against the image of the table with only a salt-cellar and a book on it suggesting a dynamic structure of equality.

Béla Tarr's very slow images are silent acts of resistance to speed. Arthur Danto mentions in Marina Abramovic's documentary about the exhibition in MoMa, The Artist is Present (2010), that visitors spend thirty seconds on average in front of a painting. Mona Lisa, thirty seconds, he adds ironically. Béla Tarr proposes a much longer immersion in the film than these thirty seconds.

In The Turin Horse, the death of film is part of a precise composition which suspends the judging aspect of its own declaration, similarly to what Gilles Deleuze writes in his book on film about suspending judgement based on Nietzsche's criticism of truth: "the true world implies a 'truthful man', a man who wants the truth, but such a man has strange motives, as he were hiding another man in him, a revenge: Othello wants the truth, but out of jealousy, or, worse, out of revenge for being black [...] The truthful man in the end wants nothing other than to judge 
life; he holds up a superior value, the good, in the name of which he will be able to judge, he is craving to judge, he sees in life an evil, a fault which is to be atoned for: the moral origin of the notion of truth. In the Nitzschean fashion, Welles has constantly battled against the system of judgment: there is no value superior to life, life is not to be judged or justified, it is innocent, it has 'the innocence of becoming' [...]" (Deleuze 2005, 133).

Around the middle of the film, when Ohlsdorfer's daughter hangs out the washed clothes in the house to protect them from the wind, the camera goes closer and closer to a piece of white clothing, and that is what we see for several seconds, the crumpled canvas with the traces of movement - this slow image pervades the final darkening of the film. This is the movie screen, with traces of life. From the most repeated situation of the film, the "sitting in front of the window," a cinema-metaphor - even if there is silence and darkness in the end - we can also sense that Tarr's films have taught us to see, to observe everywhere the film forming from connections, gestures, wind-blown leaves.

\section{References}

Brecht, Bertolt. 1964. A Short Organum for the Theatre. In Brecht on Theatre: The Development of an Aesthetic, ed. John Willett, 179-205. London: Methuen.

Deleuze, Gilles. 2005. Cinema 2: The Time-Image. London: Continuum.

Dostoyevsky, Fyodor Mikhailovich. 2005. The Idiot. New York: Barnes \& Noble Classics.

Földényi, F. László. 1999. Heinrich von Kleist: Im Netz der Wörter. [Heinrich von Kleist: In the Net of Words], München: Mathes \& Seitz.

Kant, Immanuel. 1997. The Critique of Practical Reason. Cambridge: Cambridge University Press.

Keresztury, Tibor. 1991. Félterpeszben. Arcképek az újabb magyar irodalomból. [Portraits of Emerging Writers], Budapest: Magvető.

Krasznahorkai, László. 1992. Az urgai fogoly. [The Captive from Urga], Budapest: Széphalom.

Krasznahorkai, László. 1993. A Théseus-általános. Titkos akadémiai elóadások.

[The Theseus-general. Secret Academic Lectures], Budapest: Széphalom.

Krasznahorkai, László. 1998. Megjött Ézsaiás. [Isaiah Has Come], Budapest: Magvető.

Krasznahorkai, László. 2000. The Melancholy of Resistance. New York: New Directions Books. 
Krasznahorkai, László. 2004. A torinói ló. [The Turin Horse], http://krasznahorkai. hu/docs/A_torinoi_lo_forgatokonyv.pdf. Last accessed 20. 02. 2015.

Krasznahorkai, László. 2013. Legkésőbb Torinóban [At the Latest in Turin]. In Megy a világ. [The World Goes On], 24-26. Budapest: Magvető.

Kristeva, Julia. 1989. Holbein's Dead Christ. In Black Sun. Depression and Melancholia, 105-138. New York: Columbia University Press.

Last, Angela. 2012. The End of the World - Now Prettier than Ever? http:// mutablematter.wordpress.com/2012/05/20/the-end-of-the-world-now-prettierthan-ever. Last accessed 20. 02. 2015.

Möbius, Paul Julius. 1977. Über den physiologischen Schwachsinn des Weibes. [On the Physiological Idiocy of Women], München: Matthes \& Seitz.

Nietzsche, Friedrich. 2013. On the Use and Abuse of History for Life. http:// records.viu.ca/ johnstoi/nietzsche/history.htm. Last accessed 20. 02. 2015.

Pilinszky, János. 1997. Apokripha. In The Lost Rider. A Bilingual Anthology, ed. George Szirtes. Budapest:Corvina Books. Online: http://www.c3.hu/ eufuzetek/ en/eng/14/index.php?mit=pilinszky. Last accessed 20. 02. 2015.

Rancière, Jacques. 2011. Béla Tarr, le temps d'après. [Béla Tarr, the Time After], Paris: Capricci.

Valuska, László. 2008. Az első hiba, hogy egy nézőt feltételez. [The First Mistake Is to Assume a Spectator. Interview with Béla Tarr] http://index.hu/kultur/ cinematrix/ccikkek/tarr0226/. Last accessed 20. 02. 2015. 